\title{
Molecular identification of Ornithobacterium rhinotracheale in turkeys in Isfahan province of Iran
}

\author{
Abbas Doosti ${ }^{1 *}$, Ali Sharifzadeh ${ }^{2}$, Hamed Ghasemi ${ }^{1}$ and Javad Vaez ${ }^{1}$ \\ ${ }^{1}$ Biotechnology Research Center, Islamic Azad University, Shahrekord Branch, Shahrekord, Iran. \\ ${ }^{2}$ Department of Microbiology, Faculty of Veterinary Medicine, Islamic Azad University, Shahrekord Branch, Shahrekord, \\ Iran. \\ Accepted 1 June, 2011
}

\begin{abstract}
Ornithobacterium rhinotracheale (ORT) is a gram negative, pleomorphic, rod shaped and non-motile bacterial pathogen mostly known to cause respiratory tract infections in turkeys. Ornithobacteriosis is an infectious disease of avian species that has been reported in almost all countries around the world. The objective of this study was to determine the prevalence of $O R T$ in turkeys in Isfahan province of Iran. DNA was extracted from 375 collected tracheal swabs and lungs samples and amplified by ORT 16S rRNA gene specific primers using the PCR technique. ORT DNA was detected in 75 samples $(19.93 \%)$ of broiler turkeys in Isfahan province of Iran. The results of this study demonstrated the widespread of $O R T$ in broiler turkeys and confirmed that infection with $O R T$ have a high prevalence in Iran.
\end{abstract}

Key words: Ornithobacterium rhinotracheale (ORT), turkey, polymerase chain reaction, Iran.

\section{INTRODUCTION}

Ornithobacterium rhinotracheale (ORT) isolation was identified and documented for the first time in Iran from 4week-old broilers in 2000 (Zain et al., 2008). Diverse pathogens have been recognized to cause respiratory diseases, having either a primary or secondary role. ORT, a lately reported pathogen, is a Gram-negative, pleomorphic, rod-shaped bacterium associated with respiratory disease, growth retardation, mortality and decreased egg production in poultry (Suzuki et al., 2010). ORT was reported in the meat of turkeys and broilers in South Africa, Germany, United States, France and Netherlands (Empel et al., 1997). The name Ornithobacterium was suggested for the new genera within the rRNA super family and the name rhinotracheal was suggested for the species (Koga et al., 2005). O. rhinotracheale can cause highly infectious diseases in poultry, but the severity of clinical symptoms, duration of the disease and mortality has been described to be highly variable (Bisgaard et al.,

\footnotetext{
*Corresponding author. E-mail: biotechshk@yahoo.com. Tel: +983813361001. Fax: +983813361001.
}

Abbreviation: ORT, Ornithobacterium rhinotracheale
2008). This bacterium which was previously known as Haemophilus paragallinarum causes acute respiratory disease in poultry, particularly chickens (Zain et al., 2008). The symptoms of a disease in turkey and other poultry are respiratory problems, together with purulent pneumonia, airsacculitis, severe growth retardation and rapidly increasing mortality, especially in chicken (Empel et al., 1997). Respiratory tract infection is a major problem within the poultry industry and is accompanied by a major economic loss due to retarded growth, increased medication costs, increased loss rates and poor production (Ghanbarpour and Salehi, 2009; Uriarte et al., 2010). ORT has been isolated from chicken, chukar partridge, duck, goose, guinea fowl, gull, ostrich, partridge, pheasant, pigeon, quail, rooks and turkey (Allymehr, 2006). The disease typically appears in birds 11 to 26 weeks of age, with mortality rates ranging from 3 to $7 \%$ (Amonsin et al., 1997). It was not known whether the disease outbreaks resulted from the dissemination of a single clone or from the dissemination of multiple clones (Amonsin et al., 1997). Viral and bacterial respiratory tract infections frequently occur in diseased turkeys of all ages and may cause considerable financial losses due to reduced growth, an increased mortality rate, high medication costs and a higher number of 


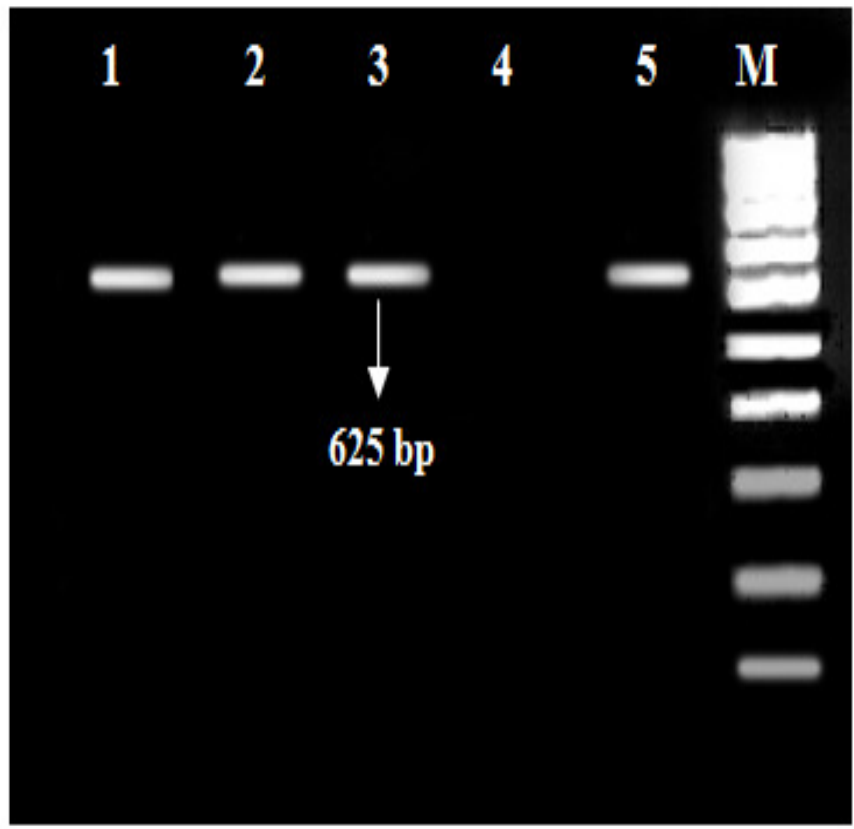

Figure 1. An agarose gel electrophoresis for PCR products of $O R T$ isolates stained with ethidium bromide (M, 100 bp DNA ladder (Fermentas, Germany); line 1 to 3 , ORT positive samples; line 4, negative control; line 5, positive control).

losses at processing (Marien et al., 2005).

$O R T$ is associated with respiratory disease, growth retardation, mortality and decreased egg production in turkeys (Canal et al., 2005). Clinical signs associated with $O R T$ infection include tracheitis, airsacculitis pericarditis, sinusitis and exudative pneumonia (Banani et al., 2001). Although microbiologic isolation and identification have been done by several investigators, there are few reports using molecular identification techniques such as polymerase chain reaction (PCR) and $16 \mathrm{~S}$ ribosomal gene sequencing because identification of $O R T$ is difficult using reliable method (Ozbey et al., 2004; Koga et al., 2005). The aim of this study was to determine the prevalence of $O R T$ in turkeys in Isfahan province of Iran using PCR and bacterial culture methods.

\section{MATERIALS AND METHODS}

\section{Sample collection}

In the fall of 2010, we collected tracheal swabs and lungs from 375 turkeys at a slaughterhouse in Isfahan province located in west of Iran and originated from 75 flocks reared in 30 farms for bacteriological examination.

\section{DNA extraction}

ORT genomic DNA was extracted using DNA extraction kit (QIAGEN Ltd., Crawley, UK) according to the manufacturer's recommendation. The extracted genomic DNA was quantified by spectrophotometric measurement at a wavelength of $260 \mathrm{~nm}$ according to the method described by Sambrook and Russell (2001).

\section{Primer design}

In this study, primers were designed according to the published sequence for $16 \mathrm{~S}$ ribosomal RNA gene of $O$. rhinotracheale (accession number: U87106). The sequence of primers pairs were as follows: forward primer was Ornitho-F: 5'-TGGCATCGATTA AAATTGAAAG-3' and reverse primer was Ornitho-R: 5'CATCGTTTACTGCGTGGACTAC-3'. These primers amplified a 625 bp fragment after $P C R$ reaction.

\section{Gene amplification}

PCR was carried out in a $25 \mu \mathrm{l}$ mixture containing $1 \mu \mathrm{g}$ of genomic DNA, $1 \mu \mathrm{M}$ of each primer (Ornitho-F and Ornitho-R), $2 \mathrm{mM} \mathrm{Mgcl}_{2}$, $200 \mu \mathrm{M}$ dNTP, $2.5 \mu \mathrm{l}$ of 10X PCR buffer and 1 unit of Taq DNA polymerase (Fermentas, Germany).

The procedure of the PCR reaction included $5 \mathrm{~min}$ of denaturation at $94^{\circ} \mathrm{C}$; followed by 32 cycles of $1 \mathrm{~min}$ at $94^{\circ} \mathrm{C}, 1 \mathrm{~min}$ at $61^{\circ} \mathrm{C}$, and $1 \mathrm{~min}$ at $72^{\circ} \mathrm{C}$, and a final extension of $72^{\circ} \mathrm{C}$ for $5 \mathrm{~min}$. The PCR amplification products $(10 \mu \mathrm{l})$ were subjected to electrophoresis in a $1 \%$ agarose gel in $1 \mathrm{X}$ TBE buffer at $80 \mathrm{~V}$ for 30 min, stained with ethidium bromide, and images were obtained in UVIdoc gel documentation systems (UK).

\section{Culture and Gram staining}

Tracheal swabs and lungs samples were cultured into 5\% sheep blood agar and incubated under microaerobic conditions (5to 10\% $\mathrm{CO}_{2}$ ). Suspected colonies were stained by Gram's methods and subcultured into chicken meat infusion (CMI) agar. 


\section{RESULTS AND DISCUSSION}

DNA was successfully extracted from samples using the DNA extraction kit and has sufficient quality for PCR amplification. Analysis of PCR products of $16 \mathrm{~S}$ ribosomal $R N A$ gene of $O$. rhinotracheale on agarose gel revealed a 625 bp fragment (Figure 1). In this study, all the collected samples were examined for the presence of ORT DNA. Out of 375 turkey samples, the prevalence of ORT was $19.93 \%$ (75 samples).

Small (1 to $3 \mathrm{~mm}$ ) grey to grey-white colonies grew on sheep blood agar after $48 \mathrm{~h}$ incubation, while on CMI agar, the colonies appeared tiny and colourless. Gram's stain showed Gram-negative, pleomorphic, rod-shaped bacteria. 24 rounded colonies, small $(0.2$ to $0.6 \mathrm{Im}$ in diameter), greyish-white and non hemolytic, with a butyric odor in bacterial cultures were revealed as ORT positive.

$O R T$ is a Gram negative, pleomorphic, rod shaped and non-motile bacterial pathogen mostly known to cause respiratory tract infections such as airsacculitis and pneumonia in birds such as turkeys and other poultry all over the world (Ghanbarpour and Salehi, 2009; Schuijffel et al., 2005). This microorganism is a new poultry pathogen associated with respiratory disease, decreased growth and increased mortality in chickens and turkeys (Chin and Droual, 1997; Hafez, 1996). The name Ornithobacterium was suggested for the new genera within the rRNA super family and the name rhinotracheal was suggested for the species (Koga et al., 2005). The first recorded isolation of $O R T$ was made from turkeys in Germany in 1981 (Banani et al., 2001). The first documented isolation and identification of ORT was made from 4 week old broiler in 2000 (Banani et al., 2001). ORT has been incriminated as a possible additional causative agent in the respiratory disease complex (Ak and Turan, 2001). The purpose of this study was to determine the prevalence of ORT according to 16S rRNA gene of this bacterium in turkeys of a broiler farm in Isfahan province of Iran using PCR and bacterial culture methods.

In the study, the prevalence of ORT in the studied region was $19.93 \%$. Suzuki and colleagues in 2010 analyzed the use of a commercial ELISA for the detection of antibody against $O R T$ in turkey serum and reported the estimates for the apparent prevalence and true prevalence at flock-level to be 30 and $17 \%$, respectively (Suzuki et al., 2010). Allymehr (2006) indicated that the prevalence of $O R T$ antibody was $92 \%$ in the broiler and broiler breeder flocks in West Azerbaijan province in northwest of Iran (Allymehr, 2006). Ozbey et al. (2004) reported that the presence of antibodies against $O R T$ was detected in $33(10.2 \%)$ of the 324 sera by ELISA and a $784 \mathrm{bp}$ fragment of the 16S rRNA gene was amplified using specific primers in the PCR. All ORT isolates that were positive by the culture were also detected to be positive by the PCR (Ozbey et al., 2004). Koga et al., (2005) indicated that out of the original 75 strains isolated from 75 clinical samples from which ORT was recovered during 1998 to 2000, 25 were selected for further study based on ORT as the primary pathogenic isolate. All the 25 strains of $O R T$ tested with rep-PCR had genetic profile similar to that of ORT American Type Culture Collection 51463 , indicating the presence of only one genotype in the ORT strains studied (Koga et al., 2005). The research of Bozorgmehrifard et al. for isolation and identification of ORT in broiler brooder flocks of Guilan province in Iran showed that present this pathogen at sample of trachea swabs from brooder flocks (Bozorgmehrifard et al., 2008). The study of Refaei et al. for detection of ORT with used the IDEXX ELISA kit from 6 broiler brooder flocks of Egypt, showed $84.6 \%$ of samples were positive (Refaei et al., 2005). Ghanbarpour and Salehi. (2009) studied on ORT prevalence and identification of ORT in broiler flocks in south-eastern Iran. In this test $42.9 \%$ strains, were identified (Ghanbarpour and Salehi, 2009). Since this study was carried out throughout the fall in 2010 (Isfahan, Iran), the higher prevalence of ORT in this study is possible. It has been reported that $O R T$ infection is at the highest rate during the cold seasons (Allymehr, 2006). Marien et al. (2005) assessed the possible synergism between ORT and Avian pneumovirus (APV), inoculated into turkeys via the natural route, for the reproduction of respiratory disease (Marien et al., 2005).

Furthermore, there are many industrial and native turkey breeding centers in all regions of Iran, especially in Isfahan province of Iran. As clearly shown, turkey is the first-rate host of ORT infection. It seemed that the existence of turkeys in this region is as a result of high prevalence of $O R T$ infection in broiler turkey.

In conclusion, the results of our investigation suggested that $O R T$ is able to adhere to and colonize the respiratory tract in cold season and the majority of ORT isolates were recovered from turkey reared in Isfahan province of Iran and many poultries from wild bird populations in other regions of the world.

\section{ACKNOWLEDGEMENTS}

This study was supported by the Biotechnology Research Center of Islamic Azad University of Shahrekord Branch in southwest of Iran.

\section{REFERENCES}

Ak S, Turan N (2001). Antimicrobial susceptibility of Ornithobacterium rhinotracheale isolated from broiler chickens in Turkey. Vet. Arch. 71 (3): 121-127.

Allymehr M (2006). Seroprevalence of Ornithobacterium rhinotracheale Infection in broiler and broiler breeder chickens in West Azerbaijan province, Iran. J. Comp. 53: 40-42.

Amonsin A, James FXW, Li LL, Vandamme P, Lindemane C, Edman M, Robinson RA, Kapur V (1997). Molecular epidemiology of Ornithobacterium rhinotracheale. JCM. 35(11): 2894-2898.

Banani M, Pourbakhsh SA, Khaki P (2001). Characterization of Ornithobacterium rhinotracheale isolates from commercial chickens. 
Arch. Razi Ins. 52(3): 27-36.

Bisgaard M, Bojesen AM, Christensen JP, Mark P, Paul FM, Janet MB, Dennis JA (2008). Infections caused by species of Pasteurellaceae, Ornithobacterium and Riemerella. An introduction. Poult. Dis. pp. 146-148.

Bozorgmehrifard S, Pourbahksh A, Banani B, Charkhkar S (2008). Isolation \& identification of Ornithobacterium rhinotracheale in broiler breeder flocks of Guilan province, north of Iran. Pak. J. Biol. Sci. 11(11): 1487-1491.

Canal CW, Lea ̃ JA, Rocha SLS, Macagnan M, Lima-Rosa CAV, Oliveira SD, Back A (2005). Isolation and characterization of Ornithobacterium rhinotracheale from chickens in Brazil. RVS., 78: 225-230.

Chin RP, Droual R (1997). Ornithobacterium rhinotracheale infection in diseases of poultry (B.W. Calnek, Ed.). 10th ed., Ames, lowa State University Press. pp. 1012-1015.

Empel PV, Bosch HVD, Loeffen P, Storm P (1997). Identification and serotyping of Ornithobacterium rhinotracheale. JCM., 35(2): 418-421.

Ghanbarpour R, Salehi M (2009). Sero-prevalence and identification of Ornithobacterium rhinotracheale in broiler flocks in south-eastern Iran. Trop. Anim. Health Prod. 41: 1679-1683.

Hafez HM (1996). Current status on the role of Ornithobacterium rhinotracheale (ORT) in respiratory disease complexes in poultry. Arch. Geflügelkd. 61: 208-211.

Koga Y, Amparo I (2005). Intraspecies genetic variability of Ornithobacterium rhinotracheale in commercial birds in Peru. Avian Dis., 49: 108-111.

Marien M, Decostere A, Martel A, Chiers K, Froyman R, Nauwynck H (2005). Synergy between avian pneumovirus and Ornithobacterium rhinotracheale in turkeys. Avian Pathol. 34(3): 204-211.
Ozbey G, Ongor H, Balik DT, Celik V, Kilic A, Muz A (2004). Investigations on Ornithobacterium rhinotracheale in broiler flocks in Elazig province located in the East of Turkey. Vet. Med. Czech. 49(8): 305-311.

Refaei M, El-Gohary A, Attia SA, Khalifa RA (2005). Diagnosis of ORT infection in chickens by ELISA. Egypt J. Immunol. 12(1): 87-93.

Sambrook J, Russell DW (2001). Molecular Cloning: A Laboratory Manual. 3rd Edition. Cold Spring Harbor Laboratory Press, Cold Spring Harbor, New York.

Schuijffel DF, van Empel PCM, Pennings AMMA, van Putten JPM, Nuijten PJM (2005). Successful selection of cross-protective vaccine candidates for Ornithobacterium rhinotracheale infection. ASM J. 73(10): 6812-6821.

Suzuki K, Petruccelli M, Trenchi G, Giossa G, Rodríguez G, Trenchi H (2010). Flock-level seroprevalence against Ornithobacterium rhinotracheale among broilers in Uruguay. Int. J. Poult. Sci. 9(2): 167170.

Uriarte J, Suzuki K, Origlia J, Gornatti D, Píscopo M, Cerda R, Herrero $M$, Marcantoni H, Unzaga MF, Spinsantti E, Marino F, Pecoraro M, Corva S, Petruccelli M (2010). Stochastic estimation of seroprevalence against Ornithobacterium rhinotracheale and avian pneumovirus among chickens in Argentina. Int. J. Poult. Sci. 9(4): 352-356.

Zain Z, Jee MTL, Jusoff K (2008). Phenotypic characteristics, antibiotic susceptibility and pathogenicity of Ornithobacterium rhinotracheale. WSEAS Trans. Biol. Biomed. 7(5): 1109-9518. 